Digilec 7 (2020), pp. 1-10

Fecha de recepción: 22/10/2020

Fecha de aceptación: 24/11/2020

DOI: https://doi.org/10.17979/digilec.2020.7.0.7085

\title{
VOICES OF SILENCED CHILDHOODS: TRANSIENCE AS DECENTERING SPATIALITY IN THREE CONTEMPORARY FILMS
}

\author{
VOCES DE UNA INFANCIA SILENCIADA: TRANSITORIEDAD \\ COMO ESPACIALIDAD DESCENTRALIZADORA EN TRES \\ PELÍCULAS CONTEMPORÁNEAS
}

\author{
Eduardo BARROS GRELA* \\ Universidade da Coruña \\ Orcid: http://orcid.org/0000-0002-7533-5580
}

\begin{abstract}
The interconnection between space production, place configuration, and identity development is interrogated in this essay through the lens of three film directors with transnational backgrounds. These auteurs introduce with Huelepega: La ley de la calle (Elia Schneider), Le temps du loup (Michael Haneke), and Children Underground (Edet Belzberg) the complications accrued by abandoned children and problematic young adults whose erratic lives have forced them to dwell in transitional places. This essay looks at the spatial consequences of the confrontation of childhood and reterritorialization, and explores the ramifications of these interactions in terms of spatiality and place resignification.
\end{abstract}

Key Words: Space; Childhood; Deterritorialization; Transience; Film

\section{Resumen}

Este artículo pone en diálogo la relación entre producción espacial, configuración del lugar y desarrollo de la identidad, para cuestionarla a través de la óptica de tres directores de cine de procedencia transnacional. En sus películas Huelepega: La ley de la calle (Elia Schneider), Le temps du loup (Michael Haneke) y Children Underground (Edet Belzberg) estos autores presentan las dificultades experimentadas tanto por niños que han sido abandonados como por jóvenes adultos problemáticos, cuyas erráticas vidas los han obligado a vivir en lugares de transición. Este ensayo analiza las consecuencias espaciales que surgen de la confrontación de la infancia y su reterritorialización, y explora las ramificaciones de estas interacciones en términos de espacialidad y resignificación del lugar.

Palabras clave: Espacio; infancia; reterritorialización; transitoriedad; cine

* Facultade de Filoloxía. Universidade da Coruña. Campus da Zapateira, s/n. 15008 A Coruña. Email: eduardo.barros@udc.es 


\section{INTRODUCTION}

Twenty-first century globalized epistemologies can be accurately described through the compelling subjectivity of deontologized children represented in the different media (Malone et al., 2020: 8). Alternative forms of subcultural otherness appear to be traced all around the globe based on inert gazes of infantility, working as both representations of inbetweeners in the age construct, and as performances of decentered identities in a (post)urban space.

After the turn of the century, film directors from diverse cultural and geographical backgrounds have converged in a deconstructive approach to the identifying representation of childhood, more specifically of what has been named as "marginal peripheries” (Preyer \& Bös, 2013: 40). Austrian filmmaker Michael Haneke in Le temps du loup (2003), American director Edet Belzberg in her 2001 documentary Children Underground, or Venezuelan Elia Schneider in Huelepega: La ley de la calle (1999) use dissimilar paths to interrogate representations of childhood in marginal spaces. Depicted through subjects affected by the problematic predicaments of the young age (Kjeldgaard and Askegaard, 2006: 236), these spaces are resignified through the low-angle of 1) a dystopian rewriting of spatial/social margins (Haneke), 2) a genderless subaltern deconstruction of the self (Belzberg), and 3) a victimized decentering of othered familial values and emptied urban spaces (Schneider).

The common epistemological spaces shared by these three films-despite their divergence in terms of original location and genre-allow this analysis to discuss the spaces of marginal childhoods from apparently different approaches and backgrounds, therefore providing evidence of the validity of its theoretical argumentation.

In this essay, thus, I look at the issues of otherness, marginalization, spatiality, and identity through a cinematic lens, as seen and performed by children, and to interrogate their displacement - or rather, their fluctuation — between the real and its imaginary other. I also question the assumed subjectivities that are globally assigned to children in general and to the ethically biased aesthetics of abandonment when applied to underage subjects.

\section{CONTEXTUALIZATION: TERRITORIES}

According to both popular media (Lévêque, 2017) and scholarly work, the field of Children and Childhood Studies entered a critical era around 2000 (Qvortrup et al., 2009: 14; Woodhead, 2008: 11). Many studies claim that the identity crisis that is characteristic of twenty-first century epistemologies is best represented through the lenses of children discursivities, which are forced to negotiate reconfigured spatialities in order to write themselves as "subjects with subjectivities” (Rumbaut, 1994: 186). This feature is clearly discussed in the narratives (literary or otherwise) that indicate an impending demise of infants and young adults as agents of their own subjectivity. Cases of abandonment, violence, physical and moral abuse are constructed to create an ethical distance from the 
projected images, and also to frame the "issue" of children as the permanent, univocally present representation of the Other (Arndt, 2018: 399; Fattore, 2016: 55).

The three cases that I explore in this article provide a vivid example of such procedures through the use of cinematic narratives. In terms of the post-Fukuyama dispute about the end of ideology (Ashcroft, 2003: 60; Fukuyama, 1992: 130), it is not surprising to see how efforts are being conducted to utilize the denotative impact of images that express identity derangement in children to question the spectator's exposure to ideology. According to Paul Waley, the "lack of visual order" in the post-industrial times both stimulates and enrages the observers of a particular performance (in fact, any given performance), creating thus a formal dependence on the irradiated assimilations of the represented children (1992: 103). In other words, the irksome situation of children who are displaced from "their childhoods" resignifies the recurring trope of either empathizing with defenseless subjects who are victimized by an unsustainable sociopolitical situation, or reifying those subjects as mere representations of our guilt as spectators.

In these three films (Le Temps du Loup, Children Underground, and Huelepega: La ley de la calle), the portrayal of children is presented through a lens of deterritorialization of their embryonic selves; that is, an ontological mechanism of struggle for regaining agency in the form of written subjectivities is applied to the manner in which young people construct their subjectivities. Territoriality is to be understood, therefore, not only as "a primary geographical expression of social power”, as Robert Sack asserts in 1983 (5), but rather as an ontological interpretation of Edward Soja’s reference to the intrinsic importance of territory: "territory provides an essential link between society and the space it occupies primarily through its impact on human interaction and the development of group spatial identities” (1971: 33).

Such an ontological re-reading of territory finds a ground of articulation in Gilles Deleuze's conceptualization of territorialization, deterritorialization, and reterritorialization (2004a: 348). In particular, deterritorialization is used to refer to a liberating displacement of the self from inert relations of power, which becomes a dexterous tool for the analysis of children's struggle against assumed subjectivities within the films discussed in this article. The raison d'être of this appeal to Deleuze's concept of deterritorialization (in order to discuss the representation of children's agency) is not to lament-from an extrinsic position - their social marginalization, but rather to turn the empathic approach from their social and aesthetic situation into a critical reflection on representability of the child as a perceptibly distant other.

In these cases, the identities of children as represented in these films might be subject to relative deterritorializations-leading to potential reterritorializations of their selves - or to absolute deterritorializations that would give way to rebuild their planes of immanence, or, in other words, to look at their pure spaces as global children. Thus, in Pure Immanence, Deleuze explains that,

We will say of pure immanence that it is a LIFE, and nothing else. It is not immanence to life, but the immanence that is in nothing is itself a life. A life is the immanence of immanence, absolute immanence: it is complete power, complete 
bliss. It is to the degree that it goes beyond the aporias of the subject and the object... (2001: 27).

In both cases, as Deleuze's proposal of reterritorialized spaces does, the articulation of territoriality with the production of identity lets its destination unwind and be formulated through the decentering process of the self. It is through this process of deterritorialization that rhizomatic structures are applied to subjectivity as a tool for subversion against power and hegemonic epistemologies:

Territorialities, then, are shot through with lines of flight testifying to the presence within them of movements of deterritorialization and reterritorialization. [...] Some are swept away by lines of flight and movements of deterritorialization, others by processes of decoding or drift, but they all communicate at the intersection of the milieus (2004a: 62).

The problematic nature of space, territory, and identity has been amply discussed by poststructuralist critics, and the results of their debates are clearly appropriate to the analysis of children's production of subjectivity in a global context (Wall, 2019a: 11; Wall, 2019b: 8). This essay is thus concerned with the articulation of the theories of decentering spatialities as applied to the representational problematic of children and childhood in film narrative. Whether the discussion of territoriality is apt to the production of space through the representation of an imagery of marginalized children will depend on the particularities of each film, and will be discussed according to the individual manifestations of an emptied epistemological center in the characters subject to discussion.

\section{HUELEPEGA: SPATIAL OTHERNESS}

Elia Schneider's 1999 Huelepega: La ley de la calle provides a sequence of incursions into the life of eight-year-old Oliver, who is thrown out of his house in Caracas and is forced to flee to the streets, trying to escape the domestic abuse, only to find-and to internalize- new forms of violent mistreatments. Such a recurrent story in films that deal with the life of abandoned children (La hora fría, Elio Quiroga (2006); Dare mo Shinarai, Hirokazu Koreeda (2004); or Lakposhtha parvaz mikonand, Bahman Ghobadi (2004), to name just a few) is intermingled in Huelepega with the story of rival drug dealers who use children to traffic in the surrounding barrios, also a frequent perspective in film narratives dealing with younger protagonists.

In Huelepega, Schneider attempts to portray the reified otherness of young subjects in economically declining urban Venezuela. The opening of his semi-documentary is preceded by a rolling text that informs about the current situation of children in Caracas:

In Venezuela 7 million children live in poverty, 4 million suffer from chronic malnutrition, 3 million are outside the education system and 600 thousand are in a state of total abandonment.

The violent deaths of children are part of everyday life for Venezuelans, being the settling of scores, family violence and death at the hands of security agencies the most frequent causes. In sites of juvenile detention fundamental human rights are violated: overcrowding, rape, abuse by police, poor nutrition and untreated diseases. 
Venezuela is one of the richest countries in Latin America, ironically in the last 40 years, far from being resolved this problem has worsened dramatically, becoming a social $\operatorname{chaos}^{1}$ (Huelepega).

This prologue should be interpreted as a guidance, addressed to the general viewer, about what the film intends to describe. Preparing the reader in such a way can only mean that Schneider, as director of this semi-documentary production, provides a selfapologetic introduction that anticipates a questionably distant approach from the horrors of abandonment and marginalization of children in Venezuela's capital. This distancing of the implied viewer from an identification with the political connotations - rather than the social connotations - of the children's empty subjectivities is managed through a playful production of intersectional gazes. Huelepega, as a production that uses both a documentary narrative and a fictional discourse, recreates a heterotopic space that situates viewers as both observers and performers of a common otherness, and this distance would then be manifested through the archetypical representation of abandoned children in common spaces of globalized urban territories. The planes of immanence that children acquire through their alienation from their own childhoods emerge from the external view provided by the director for the audience about the abandonment that the protagonist children suffer. In a similar way to what Cidade de Deus (Fernando Meirelles, 2002), Tsotsi (Gavin Hood, 2005) or Kim Ki-Duk’s Ag-o (1996) did in different geographical contexts, Huelepega uses the gargantuan and voracious urban spaces of the global slum to decontextualize the idealized image of the postindustrial city as one of minimized class differences and social inequalities. Mike Davis has amply discussed in his studies about the increase of decentered urban spaces ${ }^{2}$ how the slum epitomizes the absorption of smaller urban nuclei by gigantic cannibalistic cities, which inevitably leads to the proliferation of "children from the slums" (2007b: 43). These self-raised infants whose parents and families have ceased to show interest of any kind for them are therefore forced to create micro-universes of self-marginalization structured around a clearly dubious suitability.

Because of this vast dissemination of spatial centralities, films like Huelepega (whose title refers to the nickname that abandoned children in Caracas receive because of their addiction to inhalant sniffing ("huele"), in particular, the sniffing of glue ("pegamento"), a powerful alienating - and therefore decentering - device in itself) focus their critical eye on the effects these decentered spaces have on children, the most evident byproduct of that spatial disorganization ${ }^{3}$. As such, the film introduces the figures of these invisible children in the opening scene. A slow tracking shot depicts a series of children's silenced shadows that live under a bridge and spend their time inhaling glue.

\footnotetext{
${ }^{1}$ En Venezuela 7 millones de niños viven en estado de pobreza, 4 millones sufren de desnutrición crónica, 3 millones se encuentran fuera del sistema educativo y 600 mil están en estado de total abandono.

Las muertes violentas de menores de edad son parte de la vida diaria de los venezolanos siendo el ajuste de cuentas, la violencia familiar y la muerte en manos de organismos de seguridad las causas más frecuentes. En los sitios de reclusión de menores se violan los derechos humanos más elementales: hacinamiento, violaciones, abuso por parte de funcionarios policiales, alimentación inadecuada y enfermedades sin atención.

Venezuela es uno de los países más ricos de América Latina, contradictoriamente en los últimos 40 años, este problema lejos de solucionarse se ha agravado dramáticamente, convirtiéndose en un verdadero caos social. [Spanish in the original, my translation].

2 Davis discusses these cases particularly in Planet of Slums (2007), but also in Evil Paradises: Dreamworlds of Neoliberalism (2007), Dead Cities, And Other Tales (2003), and in many other studies.

${ }^{3}$ Spaces of the global cities are not reorganized, but rather dismembered from their organs, that is, disorganized. Both Gilles Deleuze's (2004b) and Slavoj Žižek’s (2003) studies have been seminal in the posterior discussions on the relation of space with bodies and organs.
} 
No words, no laughs, no games. There is nothing that could be typically recognizable within a child environment. On the contrary, a hostile, impacting scene welcomes the audiences into the displaced children environment posited by Huelepega, this being a heterotopic space that the spectator will not be allowed to forsake from that moment on. The accepted association of children spaces and fortunate spatialities is brutally broken with this opening sequence, and is reinforced by the upsetting physical aggressiveness of the ghostly tunnels of the dehumanized city that are so recurrent in the photography of the film.

The presence of a passing train seems to function in the narrative as a transition to a more favorable environment, probably a home atmosphere that provides the counterpoint to the ambience of abandonment. There is nothing further from the truth. The promised land of a hospitable home space is immediately broken by the physical abuse of an alcoholic parent against his wife and son. Space, in short, uses its inherent contradictions to depict the horrible violence of an urban environment that has been created to segregate into groups of class and education, yet establishes apparently hospitable territories to create the illusion of comfort.

\section{LE TEMPS DU LOUP: A PRE-TRAUMA SCENARIO}

Similarly, Austrian filmmaker Michael Haneke in Le Temps du Loup (2003) creates a very particular space to center the main actions and preoccupations of his characters. In this case, the viewer witnesses the disturbing wandering of a family around the low populated roads of what seems to be a post-apocalyptic scenario. The members of this family - parents and two children — vary as the shape of the road becomes more and more unfeasible and vast. First, the father is killed by another family who have occupied their home and feel the urge to protect their new space in order to survive. This traumatic event is, however, taken with certain apathy by the dead man's wife and children, who embark themselves in a nomadic reterritorialization of their spatialities. Uncannily represented by the polymorphic road, their ambulation is soon interrupted by the arrival of a deranged child, who is described as disrupted and abandoned, and who takes the lead of their path in order to guide them through the apparently hostile inhabitants of the road.

It will not be until the restructuration of the main spaces between the protagonists though, that the characters arrive to the place that is most significant in the development and unveiling of their identity conflicts. Again, as in the case of Huelepega, a train station becomes crucial to their "becoming". Train stations have been a frequent motive in most post-apocalyptic sceneries. The TV series The Walking Dead (2010- present time) shows railroads and stations repeatedly, as The Last of Us, the 2013 video game also does ${ }^{4}$, in what might be interpreted as a recurrent tendency of spaces that portray dystopian sceneries. Trains are naturally associated with movement and change, possibly even evolution (Daly Bednarek, 2018: 390). However, the train station depicted in Le Temps du Loup moves away from a constructive connotation as a place of rest and empowering to become an isolated and alienated signifier deprived of its original signified.

\footnotetext{
${ }^{4}$ As well as the second part of the game, The Last of Us Part Two, released in 2020 for the Play Station 4 console.
} 
The building is filled up with people who are no longer nomads in their journeys, but trapped subjects - without subjectivities, as Kelly Oliver argues - in an empty space. Running away from something that is unknown to the audience, these people follow their instincts to see the train station as a temporal place of restfulness and tranquility, but only after they have incorporated its condition of "notbeingness".

\section{CHILDREN UNDERGROUND: THE NON-PLACE OF CHILDHOOD}

Edet Belzberg portrays in her 2001 documentary Children Underground the lives of different clusters of infant individuals who are neglected by their families and are left to survive in the aggressive arteries of the Bucharest's subway. There, they create drugdealing gangs and frequently become glue-sniffing addicts in their attempt to create a rationale of their punitive situation. According to the views provided by narrators in the film, neglect plays a key_and multiple — role in these children's situation. First, parents agree with a tacit inertia of throwing their children out of the house when confronting domestic financial trouble. Even when children manage to leave temporarily their new dwelling at the subway in order to pay a visit to their parents, the latter seem excited to see them at first, but they quickly turn to their regular apathy and disregard towards their children, and frequently embark in an intimidating, rather aggressive attitude.

Also, institutions consent not only to allow but also to encourage the disavowal of these children's needs. Their approach to this problem, as we will see immediately, is rather punitive instead of integrative, therefore subjugating children to a double pressure and, subsequently, inherently criminalizing them. Local governments in Romania really see inhabitants of the underground as a problematic social burden. During Nicolei Ceaucescu's term in office, a politics of population increase was implemented to encourage national economy, but the political outcomes of the dictator's government did not go as expected and the rapidly growing population resulted in an immense proliferation of overflowing homes with little or no income. Those dysfunctional families were not able to support their children and could not afford to send them to private institutions (of course, public foster homes were nonexistent), so they ended up abandoning the younger members of the family in places where other children were already trying to survive. Belzberg's documentary looks at the actual lives of several of those children (with ages between six and sixteen), and provides a subjective view into the daily routines of these young inhabitants of Bucharest's subway.

Although this place is different to the ones taken from Huelepega and Le Temps $d u$ Loup in this analysis (in this case, children gather together and cohabitate in an abandoned and broken-down subway station), in theoretical terms the spatiality that is produced by the coexistence of place and individual subjects is the same. The underground terminal is reterritorialized by children and resignified as a dwelling location instead of a place of transit. Children recreate there the broken places of broken families that they have experienced and endured in their short lives. I have argued elsewhere that displaced subjectivities - as affected by childhood circumstances - are prone to fabricate spaces of discomfort (Barros-Grela and Bobadilla-Pérez, 2015: 82). Children Underground 
succeeds to the same degree in transporting viewers into the inconveniences of being a child — in this case, foundling children —in hostile environments. As Igor Nosál argues, abandoned children contribute to the production of urban spaces in similar ways as adults do, but they are forced to act against the given meaning of those spaces, and that is where their contribution to the deterritorialization of places occur (2009: 120). Edet Belzberg describes a group of children of ages eight to sixteen who inhabit a marginal space and have emptied its meaning by creating a group of young hoodlums who escape from physical torture from their domestic and natural places only to reproduce the toxic dynamics of their homes in their new habitat.

The subway station in Children Underground is expected to be an example of what Marc Augé coined as "non-places”, in reference to the crisis of meaning that disidentified spaces suffer - in this case, spaces that are populated by daily passengers and users of public transportation. A place of passage, a station provides a connotation of dynamic activity were children are expected to be found as excited and enthusiastic visitors. However, the homeless young inhabitants of this underground terminal modify the identity of the space to create a heterotopic_-imagined—site, in which the laughter and the voices of happy infants are silenced and substituted by invisible specters and injured shadows.

\section{CONCLUSIONS}

As seen in these three films, childhood and the production of space are intimately connected as tools of decentering spatialities. The social marginalization that is inherent to the young age is manifold and amplified by the demeaned condition of abandoned and homeless infants and adolescents. As Bolzan and Gale explain, in reference to the relationship between space and young people,

The creation of what we have called 'interrupted spaces', derived from Blaikie's work (2007), provides the opportunity for social actors to experience something different, something outside of their usual daily routine, and make meaning of it. This approach was seen as being able to extend the understandings of social resilience by creating a space in which marginalized young people were able to explore new ways of being and to have their perspectives sought and respected by adults (2012: 504).

These "interrupted spaces" are recalibrated in this essay as "interrupted nonplaces", as they are represented in the form of decentered spatialities in which children and young adults reconfigure their identities in consonance with the resignification of space-its reterritorialization. Marc Augé's concept, thus, summarizes Deleuze's discussion of territory in the terms that have been explored above, in particular through the spatial implications of these three films with regard to their introduction of subjects in a transitional age (2008: 78). These children inhabit (non-)places and participate in their transformation into a different form of interrupted (non-)places. Thus, the transient condition of those locations is replicated —and, at the same time, perpetuated — by the lack of significance of the abandoned children, who dwell in those invisible spaces as invisible subjects. 
Michael Haneke's Le temps du loup, Edet Belzberg's Children Underground, and Elia Schneider's Huelepega: La ley de la calle engage in a transnational, transdisciplinary, and transient dialog between space-particularly spatiality and the inconsistencies of territory-and age to converge in a suspension of subjectivities, as exemplified in these film directors' preoccupation with children who are represented as silenced voices.

\section{REFERENCES}

Arndt, S. (2018). Early childhood teacher cultural otherness and belonging. Contemporary Issues in Early Childhood, 19 (4), 392-403.

Ashcroft, R. E. (2003). American Biofutures: Ideology and Utopia in the Fukuyama/Stock Debate. Journal of Med Ethics, 29, 59-62.

Augé, M. (2008). Non-places: Introduction to an Anthropology of Supermodernity. London: Verso.

Barros-Grela, E. and Bobadilla Pérez (2015). Space and Children in Post-Apocalyptic Film: The Road and Les temps du loup. In The Child in Post-Apocalyptic Cinema, D. Olson (ed.), 77-90. Lanham, MD: Lexington Books.

Belzberg, E. (Director). (2001). Children Underground [Film]. Belzberg Films.

Bolzan, N. \& Gale F. (2012). Using an Interrupted Space to Explore Social Resilience with Marginalized Young People. Qualitative Social Work, 11 (5), 502-516, doi: $10.1177 / 1473325011403959$.

Daly Bednarek, J. R. (2019). Place or Non-place: The Relationship between Cities and Their Airports. Journal of Urban History, 45 (2), 386-392.

Davis, M. (2003). Dead Cities and Other Tales. London and New York: Verso. (2007a). Evil Paradises. Dreamworlds of Neoliberalism. London and New York: Verso.

(2007b). Planet of Slums. London and New York: Verso.

Deleuze, G. \& Guattari, F. (2001). Pure Immanence: Essays on a Life. (Trans. J. Raichman). New York: Zone Books.

(2004a). A Thousand Plateaus: Capitalism and Schizophrenia. London and New York: Continuum International Publishing Group.

(2004b). The Logic of Sense. London and New York: Continuum International Publishing Group.

Fattore, T. (2016). Children's Conceptions of Otherness: Constructions of the 'Moral Self' and Implications for Experiences of Migration. In Childhood, Youth and Migration, C. Hunner-Kreisel \& S. Bohne (ed.), 49-62. Berlin: Springer.

Fukuyama, F. (1992). The End of History and the Last Man. New York: Basic. Haneke, M. (Director). (2003). Le Temps du Loup. [Film]. Arte France Cinéma.

Kjeldgaard, D. \& Askegaard, S. (2006). The glocalization of youth culture: The global youth segment as structures of common difference. Journal of Consumer Research, 33 (2), 231-247. 
Lévèque, M. (2017). Les Childhood Studies in France: Esquisses d'un domaine à construire. Hypotheses.org, 9 Feb. https://magasindesenfants.hypotheses.org/5894

Malone K., Tesar, M. \& Arndt, S. (2020). History and Philosophy of Children and Childhoods. In Theorising Posthuman Childhood Studies. Children: Global Posthumanist Perspectives and Materialist Theories, K. Malone, M. Tesar, \& S. Arndt (eds.), 1-25. Berlin: Springer.

Nosál, I. (2009). Governing Abandoned Children: The Discursive Construction of Space in the Case of 'Babybox'. In Discourse and Transformation in Central and Eastern Europe, A. Galasińska \& M. Krzyżanowski (eds.), 114-136. Basingstoke: Palgrave Macmillan.

Oliver, K. (1998). Subjectivity Without Subjects: From Abject Fathers to Desiring Mothers. Lanham, Boulder, New York \& Oxford: Rowman and Littlefield Publishers.

Preyer, G. \& Bös, M. (2013). Borderlines in a Globalized World: New Perspectives in a Sociology of the World-System. Berlin: Springer.

Qvortrup, J. et al. (eds.). (2009). The Palgrave handbook of childhood studies. Basingstoke: Palgrave Macmillan.

Rumbaut, R. G. (1994). The Crucible within: Ethnic Identity, Self-Esteem, and Segmented Assimilation among Children of Immigrants. International Migration Review, 28 (4), 748-794.

Sack, R. (1986). Human Territoriality. Its Theory and History. Cambridge: Cambridge University Press.

Schneider, E. K. (Director). (1999). Huelepega. Ley de la calle. [Film]. Joel Films.

Soja, E. W. (1971) The Political Organization of Space, Washington: Association of American Geographers.

Waley, P. (1992). Fragments of a City: A Tokyo Anthology, Tokyo: The Japan Times.

Wall, J. (2019a). From childhood studies to childism: reconstructing the scholarly and social imaginations”. Children's Geographies, 1-14. https://doi.org/10.1080/14733285.2019.1668912 (2019b). Theorizing children's global citizenship: Reconstructionism and the politics of deep interdependence. Global Studies of Childhood, 9 (1), 5-17.

Woodhead, M. (2008). Childhood Studies: Past, Present and Future. In An Introduction to Childhood Studies, M. J. Kehily (ed.), 17-34. New York: McGraw-Hill Education.

Žižek, S. (2003). Organs without Bodies: Deleuze and Consequences. New York: Routledge. 